\title{
The Exploitation of Talent Capital in the Development of County Economy
}

\author{
Zhenli Gao \\ School of Management, Hefei University of Technology, Hefei City, Anhui Province, 230009, \\ China
}

Keywords: County Economy; Talent Capital; Talent Market; Talent Cultivation

\begin{abstract}
As an important capital element, talent capital is the most important factor for the development of county economy. The cultivation and exploitation of talents can provide great intellectual support for the development of county economy and can effectively promote the development of county economy. Based on the author's research and practical experience, this paper first analyzed the current situation and existing problems in the construction of county talent market and then discussed the causes of these problems. Finally, this article put forward suggestions on how to promote the cultivation and growth of talents in the county.
\end{abstract}

\section{Introduction}

In the final analysis, the development of county economy relies on people, especially on all kinds of talents who can lead and promote the development of county economy. Therefore, the talent is the first major element in the development of county economy. However, we face a serious problem in the manpower resources. That is the serious lack of various talents. In recent years, in order to promote the development of county economy, the construction of qualified personnel has received extensive attention from the society. With the heavy investment of human, material and financial resources, China has achieved remarkable results. On the whole, there still exist some problems that need to be solved. This requires relevant departments and personnel to intensify efforts to put forward appropriate strategies, so that the problems can be effectively resolved. This will pave the way for the construction of talent team at the greatest degree, so that it is possible for the further development of county economy.

\section{The Current Situation and Existing Problems in the Construction of County Talent Market}

The talent market development is unbalanced. The talent market in many counties exist many common problems: the scale is small; the service scope is narrow; the development speed is slow and the market efficiency is not high. These problems seriously restrict the function of the talent market and affect its capacity in providing talent guarantee for the development of county economy and society. From the perspective of business operation, talent markets in most counties can only carry out some general activities, such as job registration, file management, personnel agents and other businesses. It is difficult for the talent market to hold a talent exchange meeting with certain size. It means that the county has the demand for talents, but the talent market cannot satisfy this need. It does not have conditions to provide more comprehensive services for job seekers and recruiting companies.

The service function of the talent market lacks innovation consciousness. In the view of market development, there is no long-term strategic forecast and plan. It lacks innovation consciousness in market demand and market functions. In particular, there is a certain gap between the market development concept, the operation scale, service standards, service functions, and the economic and social development needs. In general, when a talent market 
carries out a business, the market in other counties will follow it. The scale of businesses is small and the services are complete. The development of some businesses still remains low-level or initial-level, which lacks characteristics of county-level talent service market.

The supply and demand subjects in the talent market is not really in place. Talent flow and allocation is still restricted by the identity, household registration, sectors and regions. Moreover, the market mechanism of independent employment of the company and individual choosing profession has not been fully established. In particular, the market foundation, supply and demand mechanism, incentive mechanism, security mechanism, policies and regulations are still the bottleneck which restricts the development of county-level talent market.

The talent market and the labor market lack a cooperation and connection mechanism. In the perspective of market construction, on one hand, the county talent market has small size, single business and weak competitiveness. Furthermore, it has not formed a cooperation mechanism. On the other hand, limited by the administrative relationship, talent market and the labor market are separated according to departments: the talent market is led by the personnel department and the labor market is subordinate to labor and social security departments. Although many businesses overlap, they just do things in their own way. Moreover, it lacks a cooperation and connection mechanism. For example, although they have some cooperation in talent output, talent exchange, graduate employment and personnel training, the cooperation types are loose and less tight, and it is just a more general contact with less empirical exchange. What's more, some markets are even closed for each other and fight alone. Talent market and the labor market have not formed a joint force, which restricts the development and growth of the talent market.

\section{Causes of These Problems}

There exists conservation and fear of difficulty in the thought. The construction of the talent market is an extremely important aspect and content in the reform of the personnel system and it plays a pivotal role in providing personnel security in the economic and social development. Due to the influence of the traditional system, there exists a conservative idea about how to adapt to the requirements of reform and opening up and the market economy development. They just attach importance to the stability and are afraid of problems. At the same time, there exists no experience and model in the construction and development of the talent market and it has a greater risk in competition in the market economy. In some counties, the talent market development is slow. The old model has operated for more than ten years and it can not advance with the times. It results in many problems: the market can not be established; the personnel cannot exchange with each other; the service does not work; the market can not function. Therefore, the talent market has no social benefits, economic benefits and talent efficiency.

The construction of talent market lacks a strategic plan. In recent years, the talent market has a faster development in hardware and service functions. However, because the county talent market lacks uniform standards in the market construction, especially in the strategic plan and systematic research of the current situation, the future development direction and objectives, and the talent management is more extensive, the main market subject is not really in place.

The market lacks an interest-driven mechanism. Like other commodities, the interest-driven mechanism plays an important regulatory role in the talent market. The talent market is one of the tertiary industries which can create social and economic benefits. Economic efficiency is an important measure for the talent market to play a role and achieve social benefits. 
At present, many county talent markets lacks awareness of goods and sense of business, so that it is difficult for the market to accelerate its development with the narrow market services and poor efficiency in society, personnel and economy.

The regulatory mechanism in the market needs to be strengthened. In a sense, the socialist market economy is legal economy and the talent market must also meet the requirements of this feature to conduct legal management. In order to make the talent market work adapt to the new situation of the development of the socialist market economy and achieve vigorous, orderly and healthy development with a correct direction, the market authorities should further strengthen the regulatory mechanism and implement legal management.

The management of talent market and labor market is disordered. After the reform and opening up, the state administrative departments set up personnel and labor departments, which formed the talent market and labor market. The talent market is responsible for exchanges of cadres and the labor market is responsible for exchanges of workers. In the actual operation, some functions of the two markets overlap. With the increase of talent, labor service, job and other intermediaries, the examination and approval of intermediaries not only needs the personnel department, but also needs labor sector and civil affairs departments. Because the examination and approval of intermediaries is controlled by many departments, there exists no relatively uniform standard in the layout of the intermediary agencies, service objects, service functions, fees, service rules and other management things. This not only damages the interests of job seekers, but also has a negative impact on the market construction.

\section{Suggestions on how to Promote the Cultivation and Growth of Talents in the County}

To deepen the understanding of the importance of human capital. The key to the development of human capital in the county is to establish a new concept of talent that human resource is the first resource. The government should establish the concept that the talent is wealth, efficiency, competitiveness and development potential. They should intensify efforts to develop human resources and attach great importance to the prominent role that outstanding talents play in the economic development. By virtue of extensive publicity of the concept that talents can promote the economic development, the whole society will respect knowledge and respect the talent. The government should educate and guide the masses to pay attention to the improvement of their own human capital. This will inject a steady stream of vitality into the county economy.

To deal with the relationship between human capital investment and material investment well. In fact, the potential rate of return on investment of human capital in China is not only far higher than the rate of return on investment of physical capital, but also higher than the rate of return on education investment in developed countries. However, policies in China is not perfect, thus making this potential rate of return on investment can not be achieved. A recent study shows that if the contribution to social output with personal income is considered, the rate of return on investment of human capital in China is as high as $30 \%$ to $40 \%$, which is higher than the rate of return on investment of physical capital (it is estimated to be as high as 20\%) and higher than the rate of return on investment of human capital (15\% to 20\%) in United States and other developed countries. Material capital and human capital investment must have an appropriate proportion. For example, low-cost labor must have high-quality staff, so as to maximize the optimization of economic production. Human capital investment and material capital investment need to be balanced. Too much emphasis on one of them will lead to lower efficiency.

To optimize the market mechanism of human capital allocation. The rational flow of 
human capital is the prerequisite and basis for the optimization of the allocation of resources. The government should actively create conditions and eliminate obstacles in the free migration and movement of labor and in the free choice of occupations, so that the human capital can maintain a strong innovation capacity and free choice right in the economy. This will promote the rational flow of human capital in the county and eliminate all institutional obstacles which hinder social resources into the field of human capital investment.

To improve the development mechanism of human capital. First of all, the government should create the education system and actively develop the education system, which includes pre-school education, basic education, adult education, vocational education and skill education. Furthermore, they should update the teaching content and reform teaching methods to effectively ensure that the content of the education and training meets the actual needs of the production. Second, the government should reform the existing household registration system and completely break the isolation between urban and rural areas to promote the free flow of labor force between urban and rural areas and between industries. Once again, the government should create the incentive mechanism and the salary system. With the help of good treatment, spiritual incentives and a series of preferential policies and measures, the government can attract foreign and local talents to develop in the county, provide a stage to high-level talent to play their role and create an atmosphere and environment of respecting talents. Finally, the government should have an innovative employing system and unswervingly implement the principles of openness, equality, competition and merit to establish a vigorous talent selecting and employing mechanism. This will create good conditions for a large number of outstanding talents.

\section{Summary}

The construction of county talent capital has attracted wide attention of the society and the country. The good work in this area can greatly promote the development of county economy. In order to make the construction of county talent capital perfect, the government must solve the existing problems, so as to provide a greater force for the construction. It should be noted that the achievement of these objectives requires sufficient support from the relevant departments and personnel, which is the basis for ensuring the successful completion of the construction.

\section{References}

[1] Hua Bei. An Analysis of Flow Effect and Changes of Human Capital in the Development of County Economy [D]. Yangzhou University, 2014.

[2] Liu Qin, Liu Ning. Exploiting Rural Human Resources and Promoting the Development of County Economy - A Case Study of Hanchuan, Hubei Province [J]. Contemporary Manager, 2006, (21): 936-937.

[3] Hao Zhaoli. A Study of the Capitalization of Human Resources [D]. Capital University of Economics and Business, 2006.

[4] Wang Yu. A Discussion on the Cultivation and Development of Talents in the Development of County Economy [J]. Anhui Agricultural Science Bulletin, 2006, (02): 13-14.

[5] Li Jianfa. Developing Human Resources and Accelerating the Development of County Economy [J]. Communist Party Members (Hebei), 2004, (07): 37.

[6] Li Jun. A Research of the Development Strategies of County Economy in Underdeveloped Areas [D]. Jilin University, 2004. 